\title{
Které hodnoty ovlivňují vstup do manželství? ${ }^{1}$
}

\section{Which Values Affect Marriage Entry?}

\author{
Martin Kreidl, Lucie Moravcová
}

\begin{abstract}
In recent decades the Czech Republic has experienced, like other countries, fundamental changes in family and reproductive behaviour - including declining marriage rates and marriage postponement. These changes are interpreted through the second demographic transition perspective, which postulates the strengthening of values that have a negative effect on individuals' decisions to marry. Nevertheless, the effect of individual value profiles on marriage entry has not been explicitly modelled. Therefore, we use data from two waves of Generations and Gender Survey from 2005 and 2008 and investigate the effect of selected values (measured in the first wave) on later marriage entry. We find only partial support for the second demographic transition theory (e.g., materialism increases the likelihood of marriage among respondents outside the labour market). Overall, we observe a much weaker effect from value variables than we expected according to the second demographic transition theory.
\end{abstract}

KEY WORDS Marriage entry, second demographic transition theory, values, Czech Republic

\section{Úvod}

V České republice, stejně jako $\mathrm{v}$ mnoha dalších zemích, došlo v posledních dekádách k zásadním změnám v rodinném a reprodukčním chování (Bongaarts 1998; Coleman 1996; Čermáková a Mař́ková 2000; de Singly 1999; Hašková a Rabušic 2008; Hoem et al. 2009; Katrňák 2001; Kreidl a Hasmanová Marhánková 2012; Kvapilová Bartošová, Fučík a Pakosta 2012; Lesthaeghe a Surkyn 2002). Např́iklad celkový počet sňatků se snížil z asi 78 tisíc v roce 1980 a 91 tisíc v roce 1990 na 55 tisíc v roce 2000 a 57 tisíc v roce 2010 (Hašková a Rabušic 2008: 12). V roce 1990 bylo v ČR uzavřeno 8,8 sňatků na 1000 obyvatel. V roce 2000 klesla hrubá míra sňatečnosti na 5,4 sňatků na 1000 obyvatel a v roce 2010 byla jen 4,4 \%o (ČSÚ 2002, 2012a). Hašková a Rabušic (2008) uvádějí, že lidé narození v 70. a 80. letech vstupují do manželství s menší intenzitou než předchozí generace, a když do něj vstupují, tak v pozdějším věku. Během 70 . a 80 . let 20 . století byl průměrný věk žen při prvním sňatku v ČR mezi 21 a 22 lety. V 90. letech poměrně prudce stoupal. V roce 2000 dosáhl asi 25 let. V roce 2006 se české ženy poprvé vdávaly průměrně přibližně v 27 letech (ČSÚ 2002, 2012a; Hašková a Rabušic 2008: 13).

Sociálni studia. Katedra sociologie FSS MU, 2/2014. S. 101-122. ISSN 1214-813X.

1 Tato studie vznikla díky finanční podpoře projektu specifického výzkumu MU, číslo projektu MUNI/A/0914/2013. 
Tyto změny bývají vykládány ze dvou perspektiv - z pozice ekonomické nejistoty a z perspektivy měnících se hodnot. Ztráta ekonomických jistot i proměna hodnotového klimatu jsou dobře popsanými fenomény (např. Kalmijn 2011; Lesthaeghe 2010; Oppenheimer 1988; Rabušic 2001; Sobotka et al. 2001). Jejich dopad na vstup do manželství byl však až dosud v ČR empiricky podchycen jen částečně. Zejména vliv hodnotového profilu jedince na vstup do manželství nebyl explicitně modelován a analytici o př́íčinném vlivu hodnot na vstup do manželství spíše spekulovali a/nebo ilustrovali vztah mezi hodnotovým profilem a volbou partnerského uspořádání na průřezových datech, která dokumentují empirickou asociaci, ale jsou jen slabou evidencí o př́ípadných kauzálních vztazích (viz např. Kreidl 2010). V této stati používáme data z longitudinální studie z let 2005-2008 a ukazujeme, jaký byl na počátku 21. století v ČR vliv vybraných hodnot (měřených v první vlně panelu) na pravděpodobnost pozdějšího vstupu do manželství.

\section{Proč dochází k odmítání (či odkládání) vstupu do manželství?}

Oppenheimer, Kalmijn a Lim (1997) ukázali na amerických datech, že načasování vstupu do manželství mladých mužů závisí na ustavení stabilní profesní dráhy. Vztah mezi ekonomickým potenciálem a šancí na vstup do manželství ale existuje jen u mladých amerických mužů, u žen se neprokázal (Xie et al. 2003). Kalmijn (2011) empiricky podporuje i starší hypotézu Oppenheimerové (1988), že profesní nejistota vede k odkládání manželství. Použivá k tomu panelová data za období 1994-2001 ze 13 evropských zemí (srov. též Bukodi 2012; Pastor 2008). Teorie o vlivu rostoucí ekonomické nejistoty na odklady manželství v době post-socialismu se objevila napřr. u Rychtaříkové (1996, 1997, 1999, 2000) nebo Stloukala (1997, 1998; srov. Sobotka, Zeman a Kantorová 2001, 2003).

Autoři zaměřující se na hodnoty jako možný důvod, proč uzavřít, či neuzavřít sňatek, často vycházejí z teorie druhé demografické tranzice (Lesthaeghe 1991-2; van de Kaa 1987) a postulují, že na celospolečenské úrovni dochází k posilování hodnot, které negativně ovlivňují individuální rozhodnutí uzavřít manželství. Thornton, Axinn a Xie (2007) např́klad zjistili, že pozitivní postoje k předmanželskému sexu a kohabitaci, ke kariéře a k výdajům za komfort zvyšují pravděpodobnost kohabitace a naopak snižují pravděpodobnost vstupu do manželství. Oproti tomu pozitivní postoje k manželství a rození dětí šanci na manželství zvyšují.

I perspektiva druhé demografické tranzice a hodnotové změny byla opakovaně aplikována na data $\mathrm{z}$ různých tranzitivních společností a nacházela $\mathrm{i}$ dílčí oporu v datech. Např. Gerber a Berman (2010) prověřovali vliv socioekonomického postavení (dosaženého vzdělání a postavení v zaměstnání) na vstup do manželství pomocí ruských dat. Ukázali, že v Rusku do manželství více vstupují lépe vzdělaní lidé (což podporuje tezi o ekonomické nejistotě, protože vzdělaní jedinci byli méně vystaveni nákladům post-socialistické transformace). Manželství nicméně v Rusku nesouvisí s ne/zaměstnaností. Nezaměstnaní muži měli menší pravděpodobnost sňatku za sovětské éry, ale ne po pádu Sovětského svazu. Autoři to vysvětlují tím, že v Sovětském svazu byla téměř plná zaměstnanost a nezaměstnanost signalizovala osobní problémy jako alkoholismus či nemoc - tedy nevhodnost partnera pro manželství (Gerber a Berman 2010: 13, 18). Pokles sňatečnosti a nárůst kohabitace v posledních 
desetiletích v Rusku považují tedy Gerber a Berman za důsledek dlouhodobého ideového posunu spiše než za krátkodobou reakci na ekonomickou a politickou krizi. Přiznávají ovšem, že neměli k dispozici explicitní indikátory hodnot, které by mohli jako vysvětlující proměnné použít $\mathrm{v}$ analýze. Na roli ideových faktorů usuzovali jen nepř́ímo.

Podobně Jones, Zhang a Zhi (2012) vysvětlují tendenci k odkládání manželství a nevstupování do manželství u svobodných Singapurců nejen vysokými finančními náklady a náklady př́ležitostí, ale také rostoucím individualismem, důrazem na svobodu, nezávislost a seberealizaci, rozšířením souhlasu s předmanželským sexem a předmanželským soužitím a celkovým posunem v postojích $\mathrm{k}$ manželství. Pracovali s kvalitativními daty, hloubkové rozhovory prováděli na přelomu let 2010/2011.

Kreidl (2012) modeloval pravděpodobnost vstupu do manželství v ČR a ukázal, že odklad manželství byl v ČR stratifikován, podobně jako v Rusku, podle dosaženého vzdělání. Nejméně vzdělaní odkládali manželství, zejména po roce 1995, silněji než jiné vzdělanostní skupiny. To indikuje, že pokles sňatečnosti závisel na disponibilních ekonomických zdrojích a/nebo výdělkovém potenciálu. Kreidl připouští, že roli mohla hrát i ideová proměna. Podtrhuje však, že jeho analýza není explicitním testem teorie druhé demografické tranzice, protože v modelu absentovala jakákoli proměnná měřící hodnotový profil respondenta.

Potarca, Mills a Lesnard (2013) srovnávají zakládání rodin v Rumunsku, Rusku a Francii. Kromě země považují za proměnné klíčové pro vysvětlení utváření partnerství a fertility kohortu a úroveň vzdělání. Postkomunistické kohorty výrazně častěji dlouhodobě žijí v nesezdaném soužití, mají v něm děti nebo jsou svobodnými rodiči. Francouzi spíše než Rumuni či Rusové volí různé formy destandardizovaného soužitíí ; tato tendence v nejmladších generacích narůstá, což autoři považují za důkaz toho, že druhá demografická tranzice zde stále pokračuje. Dále Potarca et al. (2013) předpokládají, že vyšší úroveň vzdělání ve Francii bude znamenat větší pravděpodobnost volby destandardizovaného rodinného soužití. V Rumunsku a Rusku očekávají opačný efekt vzdělání. Destandardizované formy rodinného soužití (s výjimkou rození dětí v nesezdaném soužití) jsou typické pro výše vzdělané. Síla efektu vzdělání na vznik prvního rodinného soužití se však v jednotlivých zemích liší. Ve Francii je efekt vzdělání na volbu destandardizovaných forem soužití silnější. Ze srovnání Ruska a Rumunska vyplývá, že se liší ve vývoji druhé demografické tranzice. V Rusku došlo k rozšíření západního individualistického systému hodnot, Rusové častěji volí destandardizované formy rodinného soužití. V Rumunsku je manželství stále ukotveno silnými normami, proto se tam druhá demografická tranzice projevuje spíše odkládáním manželství než volbou alternativních forem rodiny.

2 Jako referenční kategorii pro modelování zakládání rodin používají tzv. „standardní trajektorii“, která odkazuje ke klasickému sledu svobodný/á-sňatek-alespoň 2 děti v manželství. Mezi „destandardizované trajektorie“ pak řadí bezdětné manželství, manželství s jedním dítětem, odkládání založení rodiny, dlouhodobou kohabitaci, rození dětí v nesezdaném soužití a svobodné rodičovství. 


\section{Které hodnoty predikují vstup do manželství?}

Budou nás zajímat čtyři oblasti hodnot a preferencí, které by mohly predikovat vstup do manželství: hodnoty genderové rovnosti v domácnosti, důraz na seberealizaci, postmaterialismus a religiozita. Volba těchto oblastí vyplývá z dlouhodobého vývoje české společnosti s přihlédnutím $\mathrm{k}$ výše uvedeným teoretickým rámcům.

Situaci v socialistickém Československu charakterizovala, mimo jiné, nucená sekularizace, podpora participace žen na trhu práce bez změny jejich tradiční genderové role v rodině či liberální legislativa ohledně rozvodů a potratů. Po roce 1968 se česká společnost upnula k rodině, která sloužila jako sféra pro seberealizaci. Oficiální politika byla pronatalistická, manželství bylo prakticky univerzální a založení rodiny bylo pro lidi nejsnazší cestou k osamostatnění se od rodičů (Sobotka et al. 2003: 256-258). Česká společnost nicméně po roce 1989 rychle přijala západní individualistický systém hodnot. Stala se tolerantní vůči novým formám rodiny, akceptovala potraty, rozvody, mateřství svobodných matek, proměnilo se vnímání role žen ve společnosti (Sobotka et al. 2003: 259, 267), což jsou hodnoty, které byly v jiných zemích spojeny s proměnou demografického režimu.

Druhá demografická tranzice se pojí s nárůstem individuální autonomie a individuálních práv na seberealizaci, což souvisí s odmítáním autority státu a druhou vlnou sekularizace, rostoucí genderovou symetrií a pluralizací životních stylů (Lesthaeghe 2010: 246; Sobotka et al. 2003: 253-254). Základem je vzestup potřeb vyššího řádu (posun od důrazu na plnění materiálních potřeb k nemateriálním potřebám, Lesthaeghe 2010: 213). Teorie druhé demografické tranzice se v tomto bodě opírá o Inglehartovu koncepci tiché revoluce, podle níž v postindustriálních, demokratických, materiálně zajištěných společnostech dochází k přesunu důrazu od materialistických hodnot k hodnotám postmaterialistickým (Inglehart 1971).

Rabušic (2000) popisuje na datech z EVS 1991 a 1999 a ISSP 1993 pozvolný vývoj hodnotové orientace v ČR směrem k postmaterialismu. K signifikantnímu zvýšení podílu postmaterialistů došlo především u nejmladších respondentů (18-29 let). Také Řeháková (2001) analyzovala data z EVS 1991 a 1999 a potvrdila nárůst podílu postmateriálně orientovaných lidí v české společnosti. Nositelem postmateriálních hodnot je především mladší a nejvíce vzdělaná část české populace. Řeháková ale upozorňuje, že jednotlivé typy (materialisté, smíšení a postmaterialisté) se v české společnosti chovají jinak než v západních společnostech. Je to dáno především tím, že postmaterialismus se na Západě pojí s levicí a v českém kontextu s pravicí (Řeháková 2001: 48-50, 53-55, 62). Později Lakomý (2012) analyzoval data za delší časový úsek (EVS 1991, 1999 a 2008). Potvrdil nárůst podílu postmaterialistů mezi lety 1991 a 1999. Očekávání, že podíl postmaterialistů v české společnosti bude nadále růst, ale neprokázal. Doložil, že vzdělání koreluje s postmaterialismem, a to i při kontrole věku. Čím vyšší vzdělání, tím větší je pravděpodobnost postmaterialistické orientace respondenta.

Z výzkumu RODINA 1994 vyplývá, že česká rodina je ,napůl cesty mezi tradičně orientovaným modelem a změnou gender rolí“ (Čermáková 1997: 48). Reálná dělba práce uvnitř rodiny vypadá tak, že muži nenesou odpovědnost za každodenní chod rodiny. Předpokládá se, že žena kombinuje pracovní a rodinné povinnosti. Za př́ijmy do rodinného rozpočtu nicméně nesou odpovědnost oba partneři (Čermáková 1997). Pozdější šetření RODINA 1996 významnou změnu genderových rolí nezaznamenalo. Tuček a Kř́ížková (1998) na jeho 
základě předpokládali, že se rozdíly $\mathrm{v}$ domácích povinnostech mužů a žen budou vyrovnávat podobně jako profesní rozdíly. Nicméně podle projektu Podmínky pro slad'ování práce a rodiny (Český svaz žen 2003: 6) se muži i ženy stále shodují na tom, že do rodinného rozpočtu by měli přispívat oba partneři. Zároveň je však rozšiřren názor, že muž má vydělávat a žena se starat o rodinu a domácnost. Výpovědi o reálné činnosti svědčí o tom, že péče o rodinu a domácnost je častěji ženskou úlohou (Český svaz žen 2003: 6-8). Stále je zřetelná ambivalence genderových postojů, česká společnost se jen velmi málo přiblížila k genderově vyváženým postojům.

Dudová a Vohlídalová (2005: 8) ve shodě s Oppenheimer (1997: 436) poukazují na to, že manželství ztrácí pro ženy atraktivitu, protože se od nich stále očekává, že alespoň částečně podřídí profesní život zájmům rodiny. Pro ekonomicky soběstačné ženy už nicméně manželství není tak výhodné. S tím, jak roste podíl středoškolsky a vysokoškolsky vzdělaných osob v populaci (ČSÚ 2003, 2011), je konflikt mezi rostoucím důrazem na profesní uplatnění a odmítání patriarchálního modelu rodiny na straně jedné a trvající podporou tradiční dělby práce v domácnosti na straně druhé (viz Dudová a Vohlídalová 2005: 19-20) stále silnější překážou pro vstup do manželství.

V etice římskokatolické církve je spojeno manželství, sexualita a rození dětí. Nemanželské soužití a alternativní formy založení rodiny jsou nepř́ípustné. Rodina založená na manželství má v křest’anské věrouce nezastupitelné místo (Papežská rada pro rodinu 2001; Thornton et al. 1992: 629-630). Česká společnost je dlouhodobě považována za sekularizovanou (Nešpor 2010; Sobotka et al. 2003), přičemž sekularizační tendence působí především na mladší věkové kategorie (ČSÚ 2004). I přesto může i v nejmladších generacích hrát religiozita významnou roli při volbě partnerského uspořádání, protože religiózní Češi/Češky se - více než religiózní obyvatelé jiných států - skutečně chovají podle pravidel svého vyznání (Váně a Štípková 2013).

V české společnosti proběhla hodnotová proměna, která se projevuje zejména u mladší generace. Jedná se o posun směrem k postmateriálním hodnotám, zvýšení individualismu, pokles religiozity či častější uznání rovnosti mužů a žen (srov. Rabušic 2000; Řeháková 2001; Sobotka et al. 2003). Lesthaeghe (2010: 246) tyto hodnoty popisuje jako pozadí, na kterém v západní Evropě proběhl druhý demografický přechod. Pomocí druhé demografické tranzice jsou pak vysvětlovány jevy jako klesající fertilita, nárůst počtu nesezdaných soužití, růst rozvodovosti, ale také právě pokles sňatečnosti (Lesthaeghe 1991-2; Lesthaeghe 2010; van de Kaa 1987).

Jestliže chceme ověřit, zda $v$ české společnosti druhá demografická tranzice přispěla k odkládání vstupu do manželství, pak bychom měli zjistit, zda a jak hodnotový profil predikuje vstup do prvního manželství. Vzhledem k tomu, že Lesthaeghe (2010) u druhé demografické tranzice i Inglehart u postmaterialismu (1971) podmiňují př́tomnost hodnot druhé demografické tranzice či tzv. potřeb „vyššího řádu“ dosažením materiální jistoty, budeme kontrolovat, zda socioekonomický status zprostředkovává vliv hodnotového profilu na vstup do manželství a zda př́ípadně existují interakce mezi indikátory statusu a hodnot. 


\section{Předpokládané efekły vysvětlujících proměnných}

Předpokládáme, že hodnoty genderové rovnosti v zaměstnání a péči o dítě, názor na důležitost seberealizace, postmaterialismus a religiozita budou ovlivňovat vstupování do manželství.

Podle Lesthaegheho (2010: 218) jak v liberálních, tak socialistických společnostech na začátku 20. století přetrvávala tradiční dělba práce manželů (muž-živitel, žena-pečovatelka). Teprve druhá demografická tranzice a rostoucí individualismus zpochybnily autoritu genderových norem, a to především v oblasti placené práce. Lesthaeghe (2010: 223-225) dále ukazuje na prríkladu rodinného systému v zemích jižní Evropy, že zachování tradičních genderových rolí v domácnosti a péči o děti prohlubuje genderové nerovnosti na trhu práce, a přispívá tak k eliminaci součástí druhé demografické tranzice, jako jsou nesezdané soužití či rození dětí mimo manželství. Také v české společnosti být manželem a manželkou stále implikuje role živitele a pečovatelky (Sobotka et al. 2001). V souladu s předpoklady druhé demografické tranzice proto očekáváme, že lidé, kteří kladou důraz na rovnost mužů a žen (at' už v zaměstnání či v péči o děti), zůstanou zcela mimo koresidenční partnerství, nebo budou volit alternativní formy partnerského soužití, a budou tak mít menší pravděpodobnost vstupu do manželství.

Hypotéza 1A: Uznávání genderové symetrie v zaměstnání snižuje šanci na vstup do manželství.

Hypotéza 1B: Uznávání genderové symetrie v péči o děti snižuje šanci na vstup do manželství.

Dalším důležitým prvkem v pozadí druhé demografické tranzice je snaha o seberealizaci (Lesthaeghe 2010). Profesní úspěch má zvláště pro mladou generaci velký význam (Dudová a Vohlídalová 2005: 20). Snaha mladých lidí realizovat se především v práci přitom představuje překážku pro vstup do manželství. Realizace ve veřejné sféře a $\mathrm{v}$ rodině si totiž navzájem konkurují. Předpokládáme tedy, že lidé chtějící se v práci realizovat budou volit spíše alternativní formy soužití a vyhýbat se manželství.

Hypotéza 2: Vyšší dưraz na seberealizaci v zaměstnání snižuje šanci na vstup do manželství.

Podle Lesthaegheho (2010: 246) docházelo ve druhé polovině 20. století k dalšímu posilování sekularizace, který můžeme najít již v základech první demografické tranzice. Rostoucí sekularizace tak stojí také v pozadí druhé demografické tranzice. Sekularizace znamenala odklon od náboženské autority, a umožnila tak rozširrení alternativních forem rodinného života (nemanželského soužití, singles apod.). V důsledku znamená méně prostoru pro manželství. Pro sekularizovaného člověka není manželství jedinou možnou volbou, jak založit rodinu, sexuálně žít či sdílet s partnerem domácnost. Předpokládáme, že věřící lidé (v kontextu české společnosti se jedná především o katolíky) budou nicméně náboženskou etikou stále omezováni, a tudíž pravděpodobnost uzavření sňatku u nich bude vyšší než u nevěřících. 
Hypotéza 3: Religiozita pozitivně ovlivňuje vstupování do manželství.

Dále předpokládáme vztah mezi postmaterialismem a vstupováním do manželství. Postmaterialismus přitom zahrnuje oceňování seberealizace v různých doménách společnosti - ve sféře politiky, práce i rodiny (Lesthaeghe 2010: 218-219). Podle Lesthaegheho (2010) postmaterialismus leží v základech současné demografické změny a je zodpovědný za odkládání vstupu do manželství. Proto očekáváme, že materialisté budou mít oproti jinak orientovaným respondentům větší šanci na uzavření sňatku.

\section{Hypotéza 4: Materialismus pozitivně ovlivňuje vstupování do manželství.}

Podle Ingleharta (1971: 1011) postmaterialistická orientace znamená vzestup potřeb vyššího řádu, jako je individualismus a seberealizace, který je podmíněn naplněním základních potřeb, jako jsou potřeba živobytí či potřeba bezpečí. Postup demografických tranzicí (první i druhé) je spojován se zlepšujícími se životními podmínkami, růstem vzdělání a s celkovým socioekonomickým rozvojem (Lesthaeghe 2010; van de Kaa 1987, 2008). Proto se domníváme, že reálné uplatňování efektu hodnotového profilu respondenta na vstup do manželství bude podmíněno jeho socioekonomickým statusem. Tudíž že hodnoty budou zprostředkovávat vliv socioekonomického statusu na uzavírání či neuzavírání sňatků. Čistý efekt hodnot (při kontrole socioekonomického postavení) by tedy měl být slabší než efekt celkový.

\section{Data a metody}

Pro analýzu používáme data z šetření Generations and Gender Survey (GGS), ze dvou vln uskutečněných v České republice v letech 2005 a 2008. První vlna byla náhodným výběrem respondentů z české populace od 18 . roku věku $(\mathrm{N}=10006$ př́padů, návratnost $42 \%)$. Vzorek druhé vlny vycházel ze vzorku první vlny (s doplněním vzorku kvůli velké úmrtnosti [Kuchařová 2009: 3-5]). Šetření zahrnuje otázky o mezigeneračních vztazích, zakládání a vývoji partnerství, situaci v domácnosti, vzdělání, zdraví a také o postojových a hodnotových orientacích.

Analytický soubor tvoří ti z původních respondentů, kteří mohli po první vlně sběru dat uzavřít první sňatek a my se o tom dozvíme v druhém dotazování. Analyzujeme odpovědi respondentů, kteří byli podle informací v roce 2005 svobodní (nebyli nikdy ženatí či vdané) a účastnili se šetření také ve druhé vlně v roce 2008 (panel byl naneštěstí výrazně poznamenán vysokou úmrtností, ve druhé vlně se podařilo dotázat pouze cca třetinu původních respondentů). Vzhledem k tomu, že podle zjištění ČSÚ je pravděpodobnost sňatku mužů i žen starších 44 let velmi nízká - v letech 2001-2011 se pravděpodobnost prvního sňatku jak u mužů, tak u žen ve skupině ve věku 45-49 let držela pod 5\% hranicí (ČSÚ 2012b: 10-11) -, vyloučíme z analýzy respondenty, kterým bylo v době prvního dotazování 45 a více let. Analyzujeme tedy celkem 615 případů, přičemž 47 osob ve sledovaném období uzavřelo své první manželství a 568 respondentů zůstává svobodných.

Sledujeme nejprve, zda existuje vztah mezi jednotlivými studovanými hodnotovými proměnnými a vstupem do manželství. Vzhledem k tomu, že u závisle proměnné „sňatek“ rozlišujeme dvě kategorie (situaci, kdy respondent ve sledovaném období uzavřel svůj první 
sňatek [1], a situaci, kdy respondent dosud v životě sňatek neuzavřel [0]), budeme sílu jednotlivých efektů a jejich možných interakcí modelovat pomocí binární logistické regrese (Chen et al. 2013). ${ }^{3}$

Jako vysvětlující proměnné používáme hodnotové proměnné „materialismus“, „religiozita“, „,seberealizace v práci“6 a dvě genderové proměnné, „nerovnost zaměstnání a práce v domácnosti“7 a ,uznání rovnosti mužů a žen jako rodičů ${ }^{\text {“6 }}$. V analýze je používáme jako binární proměnné, které indikují pouze přítomnost nebo nepřítomnost dané charakteristiky (např. materialismus je součástí hodnotového profilu respondenta [1], materialismus není součástí hodnotového profilu respondenta [0]). Všechny hodnotové proměnné sledujeme v roce 2005.

Ke zjištění materialistické orientace byly v dotazníku použity 4 položky z Inglehartovy 12položkové baterie. Respondenti měli označit, který z cílů považují pro zemi v budoucích 10 letech za první a druhý nejdůležitější. Za materialistu je označen respondent, který v obou odpovědích zvolil materialistické položky (stabilní ekonomika a boj s kriminalitou), za postmaterialistu ten, který v obou odpovědích zvolil indikátory postmaterialismu (důležité jsou podle něj změny $\mathrm{k}$ méně neosobní a více humánní společnosti a směřování ke společnosti, kde myšlenky mají větší hodnotu než peníze), a za smíšený typ je považován respondent, který volí v jedné z odpovědí jeden z indikátorů materialismu a v další jeden z indikátorů postmaterialismu (viz SC\&C 2011a: 26; srov. Rabušic 2000: 4-9). ${ }^{4}$

Religiozitu jsme zjištovali z odpovědi na otázku „Ke kterému náboženskému vyznání se hlásíte, pokud jste věřící?“ (SC\&C 2011a: 26). Jako indikátor seberealizace v zaměstnání ${ }^{5}$ posloužila otázka: „Předložím Vám některé charakteristiky zaměstnání, které lidé považují za důležité.

Aplikace této metody na tato konkrétní data čelí dvěma problémům: useknutí dat zleva (left-truncation) a cenzorování zprava (right-censoring) (viz Cleves et al. 2010). Useknutí dat zleva pramení ze skutečnosti, že v době sběru dat pozorujeme jedince $\mathrm{z}$ různých věkových skupin, tj. nesledujeme je od okamžiku prvního vystavení riziku sledované události (k nástupu rizika dochází podle české legislativy v 18 letech, v př́ípadě soudního zplnoletnění i dř́ve), ale často je první rozhovor (a tedy i měření klíčových hodnotových proměnných) proveden v pozdějším věku. Proto ve starších věkových skupinách nepozorujeme jedince, kteří měli nejsilnější tendenci zažít sledovanou událost (manželství), a analyzujeme tedy specifický selektivní vzorek. Specifičnost vzorku roste s věkem při prvním rozhovoru. Cenzorování zprava znamená, že někteří jedinci v analytickém vzorku ještě stále v době druhého rozhovoru nezažili sledovanou událost. To ale neznamená, že ji nemohou zažít v nějakém pozdějším okamžiku. Cenzorování zprava je v principu řešitelné použitím jiné analytické metody (např. by mohlo jít o analýzu přežití), useknutí dat zleva představuje větší komplikaci (Guo 1993). V souhrnu se nám zdá, že použití jiné analytické metody nedává garanci validnějších výsledků.

4 Kvůli distribuci odpovědí po zařazení kontrolních proměnných jsme upustili od použití proměnné „postmaterialismus“ a používáme binární proměnnou „materialismus“, kdy materialismus je př́itomen (1), pokud jsme respondenta zařadili do kategorie materialistů, referenční kategorii (0) pak tvoří respondenti postmaterialistické a smíšené orientace.

5 Jako religiózní byli označeni respondenti, pokud se k některému z náboženských vyznání přihlásili (1), jako nereligiózní byli označeni ti, již se k žádnému náboženskému vyznání nepřihlásili (0).

6 Kladná hodnota proměnné „,seberealizace v práci“ odkazuje na respondenty, kteří ze jmenovaných charakteristik zaměstnání zvolili jako nejdůležitější jednu z následujících: možnost se v práci prosadit, něčeho v ní dosáhnout a využívat v ní své schopnosti. Pro ostatní respondenty nabývá tato proměnná hodnotu 0 . 
Podívejte se, prosím, na ně a řekněte mi, které osobně považujete v zaměstnání za důležité. Vyberte, prosím, maximálně 3 a seřad’te je podle pořadí důležitosti“ (viz SC\&C 2011a: 27).

Dále měli respondenti vyjádřit souhlas, či nesouhlas (na pětibodové škále) s výroky „Starat se o domácnost a rodinu je stejně uspokojující jako vydělávat peníze“7 a „Pokud se rodiče rozvedou, je pro dítě lepší, když zůstane s matkou než s otcem“"8 (SC\&C 2011a: 28). Jestliže respondent s výroky nesouhlasil, považovali jsme to za výraz uznání genderové rovnosti a proměnné „nerovnost zaměstnání a práce v domácnosti“ a „uznání rovnosti mužů a žen jako rodičư “ nabývaly kladných hodnot.

Dále nás zajímá, zda vztah mezi hodnotovým profilem respondenta a uzavřením sňatku přetrvá i při kontrole dalších proměnných. Primárně budeme sledovat socioekonomické postavení respondenta - hlavní aktivitu ${ }^{9}$ a nejvyšší ukončené vzdělání1 ${ }^{10}$, dále pohlaví a věk ${ }^{11}$. Všechny kontrolní proměnné měříme v roce 2005.

Tabulka 1: Třídění podle hlavní ekonomické aktivity v roce 2005.

\begin{tabular}{|l|l|c|}
\hline Proměnná & Hlavní ekonomická aktivita & $52 \%$ \\
\hline Pracující (1) & Zaměstnanec, OSVČ & $34 \%$ \\
\hline $\begin{array}{l}\text { Jiná hlavní ekonomická aktivita } \\
\text { (0- ref. kategorie) }\end{array}$ & Student, žák, učeň & $8 \%$ \\
\hline & Nezaměstnaný & $3 \%$ \\
\hline & Rodičovská dovolená & $2 \%$ \\
\hline & Invalidní důchodce & $1 \%$ \\
\hline & $\begin{array}{l}\text { Pomáhající člen rodiny, v domácnosti, jiná } \\
\text { nespecifikovaná ekonomická aktivita }\end{array}$ & $0 \%$ \\
\hline & Starobní důchodce & $100 \%$ \\
\hline
\end{tabular}

Zdroj: GGS 2005, N = 615.

7 Kladná hodnota proměnné „nerovnost zaměstnání a práce v domácnosti“ odkazuje k nesouhlasu respondentů s tímto výrokem. Hodnotu 0 nabývá u respondentů, kteří s výrokem souhlasili či k němu zaujali neutrální postoj.

8 Kladná hodnota proměnné „,uznání rovnosti mužů a žen jako rodičư“ odkazuje k nesouhlasu s tímto výrokem. Hodnotu 0 nabývá u respondentů, kteří s výrokem souhlasili či k němu zaujímali neutrální postoj.

9 Budeme srovnávat skupinu pracujících (1), kam řadíme zaměstnance a OSVČ, a ostatní aktivity (0), které vykonávají nezaměstnaní, invalidní důchodci, studenti, lidé na rodičovské dovolené, v domácnosti a pomáhající členové rodiny (viz SC\&C 2011b: 12).

10 V analýze používáme tři vzdělanostní kategorie. Jako vysokoškolsky vzdělané jsme označili respondenty s ukončeným bakalářským, magisterským či postgraduálním vzděláním, jako respondenti s maturitou jsou označeni ti, kteří absolvovali úplné stř̌ední vzdělání s maturitou nebo nástavbové vzdělání. Respondenti s nižším nejvyšším dosaženým vzděláním spadají do referenční skupiny (viz SC\&C 2011a: 5).

11 Respondenti, jimž v roce 2005 bylo 18-24 let, tvoří referenční skupinu; v analýze figurují věkové skupiny 25-29, 30-34, 35-39 a 40-44 let. Při modelování některých interakcí došlo ke sloučení některých věkových kategorií $\mathrm{z}$ důvodu nedostatku případů $\mathrm{v}$ jednotlivých podskupinách (blíže viz „Výsledky“). 
Vzorek svobodných, se kterým pracujeme, obsahuje 615 př́padů. Asi tři čtvrtiny z nich v roce 2005 ještě nedosáhly 30. roku věku, téměř polovina byla v té době mladší 25 let. To, že je věková struktura analyzovaného vzorku významně vychýlená ve prospěch mladších respondentů, je dáno v první řadě tím, že starší respondenti, kteří vstoupili do manželství už dříve v průběhu životního běhu, se do našeho výběru nedostali. Ve vzorku převažují muži (65 \%) nad ženami (35\%). Zaměstnání či podnikání bylo hlavní ekonomickou aktivitou poloviny respondentů a tvoří kategorii „pracující“. Jako referenční kategorie pro ekonomickou aktivitu slouží ,jiná hlavní aktivita“, do níž řadíme všechny ostatní ekonomické aktivity (Tabulka 1). Lidé s nejnižším vzděláním, tvořící referenční kategorii pro vzdělání, tvoří mírnou většinu vzorku. Je to způsobeno tím, že náš vzorek je poměrně mladý a značná část respondentů stále studuje. Jedenáct procent respondentů má ukončené vysokoškolské vzdělání a 36\% respondentů dosáhlo maturitního vzdělání. Jak byli ve výběrovém souboru zastoupeni respondenti se sledovanými hodnotovými charakteristikami, znázorňuje Tabulka 2.

Tabulka 2: Zastoupení sledovaných hodnotových proměnných ve výběrovém souboru.

\begin{tabular}{|l|c|}
\hline Hodnotový profil v r. $\mathbf{2 0 0 5}$ & $39 \%$ \\
\hline Materialismus & $22 \%$ \\
\hline Religiozita & $69 \%$ \\
\hline Seberealizace & $30 \%$ \\
\hline Nerovnost zaměstnání a práce v domácnosti & $20 \%$ \\
\hline Uznání rovnosti mužů a žen jako rodičů & \\
\hline
\end{tabular}

Zdroj: GGS 2005, $\mathrm{N}=615$.

\section{Výsledky}

Základní modely binární logistické regrese (M1-M5) obsahují každý po jedné vysvětlující hodnotové proměnné. Efekty jednotlivých hodnotových proměnných jsou velmi slabé a statisticky i věcně nevýznamné (viz Tabulka 3). Po přidání kontrol, respektive některých interakcí hodnotových a kontrolních proměnných, vznikají modely, které data predikují výrazně lépe (viz Tabulky 4-8).

Tabulka 3: Odhadnuté efekty jednotlivých hodnotových proměnných na přirozený logaritmus šance, že respondent během sledovaného období uzavře první sňatek.

\begin{tabular}{|c|c|c|}
\hline Hodnota X & Efekt X & p-hodnota \\
\hline Materialismus (model M1) & $-0,041$ & 0,90 \\
\hline Religiozita (model M2) & 0,324 & 0,34 \\
\hline Seberealizace (model M3) & $-0,340$ & 0,28 \\
\hline Nerovnost zaměstnání a práce v domácnosti (model M4) & $-0,144$ & 0,67 \\
\hline Uznání rovnosti mužů a žen jako rodičů (model M5) & 0,207 & 0,57 \\
\hline
\end{tabular}

Zdroj: GGS 2005, 2008. N = 615 . 
V Tabulce 4 prezentujeme statistiky vhodnosti modelů, v nichž je jako jedna z vysvětlujících proměnných použit „materialismus“. Model M6 zahrnuje jako vysvětlující proměnné „materialismus“ a všechny kontrolní proměnné v aditivní podobě. Rozšířením o interakce materialismu se vzděláním (M7), materialismu s pohlavím (M9) ani materialismu s věkem nezískáme modely vhodnější $\mathrm{k}$ explanaci uzavření prvních sňatků během sledovaného období. Ve všech př́ipadech vede test hypotézy, že je možné tyto interakce z modelu vyloučit, k poměrně vysokým p-hodnotám. Například srovnání M6 a M7 vede k L ${ }^{2}=1,91$ při 2 stupních volnosti, což implikuje $\mathrm{p}=0,38$, takže interakci mezi materialismem a vzděláním považujeme za nevýznamnou. Podobně je nevýznamná interakce mezi materialismem a pohlavím (srovnání M6 a M9, $\mathrm{L}^{2}=0,37$, d.f. = 1, p =0,54). Důležitou se jeví být interakce materialismu a hlavní ekonomické aktivity (M8), která statisticky významně přispívá k tomu, aby model lépe predikoval data, přinejmenším na hladině významnosti 0,1 (viz kontrast modelů M8 a M6 v tabulce 4; $\mathrm{L}^{2}=3,12$ při 1 stupni volnosti). Proto pro věcný výklad vlivu postmaterialismu na pravděpodobnost vstupu do manželství preferujeme model M8.

Tabulka 4: Srovnání modelů s proměnnou „materialismus“.

\begin{tabular}{|c|c|c|c|c|}
\hline Model & Popis modelu & L2 & d.f. & $\mathbf{p}$ \\
\hline M6 & Ml + vzdělání, ekonomická aktivita, věk, pohlaví & 28,73 & 10 & 0,00 \\
\hline M7 & M6 + interakce materialismu a vzdělání & 30,64 & 12 & 0,00 \\
\hline M8 & M6 + interakce materialismu a ekonomické aktivity & 31,85 & 11 & 0,00 \\
\hline M9 & M6 + interakce materialismu a pohlaví & 29,10 & 11 & 0,00 \\
\hline M10 & M6 + interakce materialismu a věku & 29,43 & 14 & 0,01 \\
\hline \multicolumn{5}{|l|}{ Kontrasty } \\
\hline M7-M6 & & 1,91 & 2 & 0,38 \\
\hline M8-M6 & & 3,12 & 1 & 0,08 \\
\hline M9-M6 & & 0,37 & 1 & 0,54 \\
\hline M10-M6 & & 0,70 & 4 & 0,95 \\
\hline
\end{tabular}

Zdroj: GGS 2005, $\mathrm{N}=615$.

Poznámka: $L^{2}$ - hodnota testového kritéria pro test věrohodnostním poměrem; d.f. - počet stupňů volnosti; $\mathrm{p}-\mathrm{p}$-hodnota.

Obdobně jsou v Tabulce 5 prezentovány statistiky vhodnosti modelů používajících „religiozitu“ jako jednu z vysvětlujících proměnných. K modelu M11 obsahujícímu religiozitu a kontrolní proměnné jsou v modelech M12-M15 přidány některé interakce, které nepřispívají k lepší predikci hodnot závisle proměnné (p-hodnoty jsou 0,37 pro interakci religiozity a vzdělání, 0,41 pro interakci religiozity a ekonomické aktivity, 0,48 pro interakci religiozity a pohlaví a konečně 0,69 pro interakci religiozity a věku, viz Tabulka 5). Proto dáme při interpretaci efektu ,religiozity“ na vstup do manželství přednost prostému aditivnímu modelu religiozity a kontrolních proměnných (M11). 
Tabulka 5: Srovnání modelů s proměnnou „religiozita“.

\begin{tabular}{|l|l|r|r|c|}
\hline Model & Popis modelu & L2 & d.f. & p \\
\hline M11 & M2 + vzdělání, ekonomická aktivita, věk, pohlaví & 28,63 & 10 & 0,00 \\
\hline M12 & M11 + interakce religiozity a vzdělání & 30,63 & 12 & 0,00 \\
\hline M13 & M11+ interakce religiozity a ekonomické aktivity & 29,32 & 11 & 0,00 \\
\hline M14 & M11+ interakce religiozity a pohlaví & 29,13 & 11 & 0,00 \\
\hline M15 & M11+ interakce religiozity a věku & 30,91 & 14 & 0,00 \\
\hline Kontrasty & \multicolumn{3}{|c|}{2} & 0,37 \\
\hline M12-M11 & & 2,00 & 2 & 0,41 \\
\hline M13-M11 & & 0,69 & 1 \\
\hline M14-M11 & & 0,50 & 1 & 0,48 \\
\hline M15-M11 & & 2,28 & 4 & 0,69 \\
\hline
\end{tabular}

Zdroj: GGS 2005, 2008. N = 615.

Poznámka: $\mathrm{L}^{2}$ - hodnota testového kritéria pro test věrohodnostním poměrem; d.f. - počet stupňủ volnosti; $\mathrm{p}$ - p-hodnota.

Ani interakce „seberealizace v zaměstnání“ s kontrolními proměnnými (v modelech M17M20, viz Tabulka 6) ve srovnání s modelem M16 bez interakcí statisticky významně nepřispívá k lepší predikci dat (Tabulka 6). Proto při interpretaci vlivu „,seberealizace v zaměstnání“ využijeme hodnoty efektů odhadnutých v modelu M16, který interakce neobsahuje.

Tabulka 6: Srovnání modelů s proměnnou „seberealizace“.

\begin{tabular}{|c|c|c|c|c|}
\hline Model & Popis modelu & L2 & d.f. & $\mathbf{p}$ \\
\hline M16 & M3 + vzdělání, ekonomická aktivita, věk, pohlaví & 30,50 & 10 & 0,00 \\
\hline M17 & M16 + interakce seberealizace a vzdělání & 31,39 & 12 & 0,00 \\
\hline M18 & M16 + interakce seberealizace a ekonomické aktivity & 31,44 & 11 & 0,00 \\
\hline M19 & M16 + interakce seberealizace a pohlaví & 31,19 & 11 & 0,00 \\
\hline M20 & M16 + interakce seberealizace a věku & 31,23 & 14 & 0,00 \\
\hline \multicolumn{5}{|l|}{ Kontrasty } \\
\hline M17-M16 & & 1,34 & 2 & 0,51 \\
\hline M18-M16 & & 1,39 & 1 & 0,24 \\
\hline M19-M16 & & 1,14 & 1 & 0,29 \\
\hline M20-M16 & & 1,19 & 4 & 0,88 \\
\hline
\end{tabular}

Zdroj: GGS 2005, 2008. N = 615 .

Poznámka: $L^{2}$ - hodnota testového kritéria pro test věrohodnostním poměrem; d.f. - počet stupňu volnosti; $\mathrm{p}-\mathrm{p}$-hodnota.

Tabulka 7 obsahuje hodnoty statistik vhodnosti pro modely obsahující proměnnou „,nerovnost zaměstnání a práce v domácnosti“، Model M21 je prostým aditivním modelem této hodnotové proměnné a všech kontrolních proměnných. Také model M25 kombinuje vysvětlení pomocí proměnné „nerovnost zaměstnání a práce v domácnosti“ a kontrolních proměnných. 
Rozdíl je v tom, že model M25 pracuje s upravenými věkovými kategoriemi ${ }^{12}$. Testové statistiky v dolní části Tabulky 7 ukazují, že interakce použité v modelech M22-M24 a M26 významně nepřispívají k lepší predikci toho, zda respondent vstoupí, či nevstoupí do manželství. Například test hypotézy, že lze z Modelu 22 vynechat interakci mezi vyznáváním rovnosti zaměstnání a práce $\mathrm{v}$ domácnosti se vzděláním, vede $\mathrm{k} \mathrm{L}^{2}=2,15$ při 2 stupních volnosti, což vede $\mathrm{k} \mathrm{p}=0,34$. Podobně vysoké $\mathrm{p}$-hodnoty získáme při testování interakcí mezi rovností zaměstnání a domácnosti a ekonomické aktivity (v Modelu M23, p = 0,61, viz Tabulku 7).

Tabulka 7: Srovnání modelů s proměnnou „nerovnost zaměstnání a práce v domácnosti““.

\begin{tabular}{|c|c|c|c|c|}
\hline Model & Popis modelu & L2 & d.f. & p \\
\hline M21 & M4 + vzdělání, ekonomická aktivita, věk, pohlaví & 28,45 & 10 & 0,00 \\
\hline M22 & $\begin{array}{l}\text { M21 + interakce nerovnosti zaměstnání a práce } \\
\text { v domácnosti a vzdělání }\end{array}$ & 30,59 & 12 & 0,00 \\
\hline M23 & $\begin{array}{l}\text { M21 + interakce nerovnosti zaměstnání a práce } \\
\text { v domácnosti a ekonomické aktivity }\end{array}$ & 28,71 & 11 & 0,00 \\
\hline M24 & $\begin{array}{l}\text { M21 + interakce nerovnosti zaměstnání a práce } \\
\text { v domácnosti a pohlaví }\end{array}$ & 28,50 & 11 & 0,00 \\
\hline M25 & $\begin{array}{l}\text { M4 + vzdělání, ekonomická aktivita, věk (25-29, 30-34, } \\
35+) \text {, pohlaví }\end{array}$ & 28,20 & 9 & 0,00 \\
\hline M26 & $\begin{array}{l}\text { M25 + interakce nerovnosti zaměstnání a práce } \\
\text { v domácnosti a věku }(25-29,30-34,35+)\end{array}$ & 29,23 & 12 & 0,00 \\
\hline \multicolumn{5}{|l|}{ Kontrasty } \\
\hline M22-M21 & & 2,15 & 2 & 0,34 \\
\hline M23-M21 & & 0,26 & 1 & 0,61 \\
\hline M24-M21 & & 0,06 & 1 & 0,81 \\
\hline M26-M25 & & 1,03 & 3 & 0,79 \\
\hline
\end{tabular}

Zdroj: GGS 2005, 2008. N = 615.

Poznámky: $\mathrm{L}^{2}$ - hodnota testového kritéria pro test věrohodnostním poměrem; d.f. - počet stupňu volnosti; $\mathrm{p}$ - p-hodnota.

Věk - respondenti ve věku 18-24 let tvořili referenční kategorii a v modelu figurují kategorie 25-29, 30-34, 35-39 a 40-44 let; věk (25-29, 30-34, 35+) - respondenti ve věku 18-24 let tvořili referenční kategorii a v modelu figurují kategorie 25-29, 30-34 a 35 a více let.

12 Zatímco v modelu M21 jsou použity věkové kategorie 18-24 (referenční kategorie), 25-29, 30-34, 35-39 a 40-44 let. V modelu M25 jsou kategorie 35-39 a 40-44 let sloučeny do jedné věkové kategorie 35+. K této úpravě došlo kvůli možnosti srovnání s modelem M26, který použíá interakci „nerovnosti zaměstnání a práce v domácnosti“ a upraveného věku. Model M26 by v príípadě použití původních věkových kategorií neobsahoval v jednotlivých podskupinách dostatečné množství př́padů a neměli bychom tak možnost zjistit, zda interakce nesouhlasu s rovností placené práce a práce v domácnosti s věkem přispívá k lepší predikci vstupu do manželství. V modelech M22-24, obsahujících interakce genderové proměnné s nejvyšším ukončeným vzděláním, hlavní ekonomickou aktivitou nebo pohlavím, bylo možné použít původní věkové kategorie, které nevstupovaly do interakce s použitou hodnotovou proměnnou. 
Interakce mezi vyznáváním rovnosti práce v zaměstnání a práce v domácnosti a pohlavím je ještě méně významná ( $\mathrm{p}$-hodnota = 0,81, viz srovnání Modelů M24 a M21). Pro věcný výklad vstupování do manželství v př́ípadě proměnné „,nerovnost zaměstnání a práce v domácnosti““ proto preferujeme model M21 (viz Tabulka 7).

Modely s druhou genderovou proměnnou, jejíž kladná hodnota vyjadřuje souhlas respondenta s rovností mužů a žen jako rodičů, a jejich statistiky vhodnosti najdeme v Tabulce 8. Model M27 obsahuje kromě „uznání rovnosti mužů a žen jako rodičư“ všechny kontrolní proměnné. Model M31 také, došlo v něm ale opět k úpravě věkových kategorií1 ${ }^{13}$. Při kontrastování modelů se ukázala důležitost interakce ,uznání rovnosti mužů a žen jako rodičů “ s nejvyšším ukončeným vzděláním (viz kontrast modelů M28 a M27 v Tabulce 8; L2 = 4,56 při 2 stupních volnosti, $\mathrm{p}=0,10$ ) a interakce ,uznání rovnosti mužů a žen jako rodičư “s hlavní ekonomickou aktivitou (viz kontrast modelů M29 a M27 v tabulce $8 ; \mathrm{L}^{2}=5,27$ při 1 stupni volnosti, $\mathrm{p}=0,02$ ). Interpretovat proto budeme efekty odhadnuté v modelech M28 a M29, které indikují, že se efekt vyznávané hodnoty rovnosti rodičů v péči o děti liší podle dosaženého vzdělání a ekonomické aktivity.

Tabulka 8: Srovnání modelů s proměnnou „uznání rovnosti mužůa a žen jako rodičůu“.

\begin{tabular}{|c|c|c|c|c|}
\hline Model & Popis modelu & L2 & d.f. & $\mathbf{p}$ \\
\hline M27 & M5 + vzdělání, ekonomická aktivita, věk, pohlaví & 28,9 & 10 & 0,00 \\
\hline$M 28$ & $\begin{array}{l}\text { M27 + interakce uznání rovnosti mužů a žen jako rodičů } \\
\text { a vzdělání }\end{array}$ & 33,46 & 12 & 0,00 \\
\hline M29 & $\begin{array}{l}\text { M27 + interakce uznání rovnosti mužů a žen jako rodičů } \\
\text { a aktivity }\end{array}$ & 34,17 & 11 & 0,00 \\
\hline M30 & $\begin{array}{l}\text { M27 + interakce uznání rovnosti mužů a žen jako rodičů } \\
\text { a pohlaví }\end{array}$ & 29,68 & 11 & 0,00 \\
\hline M31 & M5 + vzdělání, ekonomická aktivita, věk (25-29, 30+), pohlaví & 26,21 & 8 & 0,00 \\
\hline M32 & $\begin{array}{l}\text { M31 + interakce uznání rovnosti mužů a žen jako rodičů } \\
\text { a věku }(25-29,30+)\end{array}$ & 28,26 & 10 & 0,00 \\
\hline \multicolumn{5}{|l|}{ Kontrasty } \\
\hline M28-M27 & & 4,56 & 2 & 0,10 \\
\hline M29-M27 & & 5,27 & 1 & 0,02 \\
\hline M30-M27 & & 0,78 & 1 & 0,38 \\
\hline M32-M31 & & 2,05 & 2 & 0,36 \\
\hline
\end{tabular}

Zdroj: GGS 2005, 2008. N =615.

Poznámky: $\mathrm{L}^{2}$ - hodnota testového kritéria pro test věrohodnostním poměrem; d.f. - počet stupňů volnosti; $p$ - p-hodnota.

Věk - respondenti ve věku 18-24 let tvořili referenční kategorii a v modelu figurují kategorie 25-29, 30-34, 35-39 a 40-44 let; věk $(25-29,30+)$ - respondenti ve věku 18-24 let tvořili referenční kategorii a v modelu figurují kategorie $25-29$ a 30 a více let.

13 V modelu M31 slouží jako referenční věková kategorie 18-24 let, dále je použita kategorie 25-29 let a kategorie 30+, která pokrývá tři původní věkové kategorie 30-34, 35-39 a 40-44 let. K úpravě došlo kvůli možnosti srovnání s modelem M32, ve kterém jsou použity interakce „uznání rovnosti mužů a žen jako rodičů“ a upravených věkových kategorií. 
V Tabulce 9 prezentujeme odhadnuté efekty vybraných modelů. U každé hodnotové proměnné interpretujeme preferované modely, které vyplynuly z výše představeného statistického srovnání. V Modelu M8 vidíme, že efekt „materialismu“ pro respondenty s ,jinou hlavní ekonomickou aktivitou“ je velmi silný a kladný $(1,006)$. Pokud je člověk s jinou hlavní ekonomickou aktivitou materialista, jeho šance na sňatek je oproti ne-materialistům 2,7 násobná, protože $\exp (1,006)=2,7$. Efekt „materialismu“ pro „pracujícíc je záporný $(-0,223=-1,229+1,006$, viz Tabulka 9). Vzhledem $\mathrm{k}$ tomu, že exp $(-0,223)=0,8$, má pracující materialista o $20 \%$ menší šanci, že uzavře sňatek, než pracující ne-materialista. Ergo, materialismus vede $\mathrm{k}$ vyšší pravděpodobnosti vstupu do manželství pouze u respondentů mimo trh práce, což můžeme vnímat jako dílčí potvrzení teorie druhého demografického přechodu.

Efekt religiozity (viz model M11 v Tabulce 9) zůstává i při kontrole vzdělání, hlavní ekonomické aktivity, věku a pohlaví slabý $(0,180)$ a statisticky nevýznamný $(\mathrm{p}=0,61)$. Rozdíl mezi religiózními a nereligiózními v intenzitě vstupování do manželství se tudíž neprokázal. Lesthaeghe a Surkyn (2002) zkoumali vztah mezi novými formami rodiny a hodnotovými orientacemi. V datech EVS rozdělili země do tří větších skupin a ukázali, že zatímco $\mathrm{v}$ západních zemích se sekulární orientace pojí s volbou alternativních forem rodinných uspořádání, jako je kohabitace, v zemích východní a střední Evropy (kam patří i ČR) není spojení sekularismu a netradičních forem rodiny tak zřetelné. Vysvětlují to sekulární tradicí, která vyplývá z komunistické historie zemí východní a střední Evropy.

Efekt „,seberealizace v práci“ má zápornou hodnotu (-0,440; viz model M16 v Tabulce 9), v našem výběrovém souboru tedy seberealizace skutečně snižuje šanci na vstup do manželství, jak jsme předpokládali. Studie provedené v jiných kontextech také naznačovaly, že pozitivní postoje ke kariéře a důraz na seberealizaci snižují pravděpodobnost sňatku (Thornton, Axinn a Xie 2007; Jones, Zhang a Zhi 2012). Přestože jsme na základě českých dat zjistili poměrně silný záporný vliv seberealizace v práci na vstupování do manželství, je vhodné toto zjištění interpretovat jen s opatrností jako náznak platnosti teorie druhého demografického přechodu. Protože hodnota efektu „seberealizace“ nedosahuje statistické signifikance $(\mathrm{p}=0,19)$.

Slabý záporný efekt má v našem výběrovém souboru „,nerovnost zaměstnání a práce v domácnosti“ $(-0,086 ; p=0,81$; viz model M21 v Tabulce 9$)$ a tato hodnotová proměnná se tedy nechová $\mathrm{v}$ souladu se vstupními teoretickými předpoklady.

V modelu M28 jsme odhadovali interakční efekty „uznání rovnosti mužů a žen jako rodičů“ a nejvyššího ukončeného vzdělání. V Tabulce 9 vidíme u modelu M28 efekt „uznání rovnosti mužů a žen jako rodičů “ pro lidi se základním vzděláním, který má hodnotu $-0,453$ a není statisticky významný $(\mathrm{p}=0,56)$. Zatímco u středoškoláků $\mathrm{v}$ našem výběrovém souboru se efekt „uznání rovnosti mužů a žen jako rodičư“ ztrácí (dosahuje hodnoty $-0,002$ = $-0,453+0,451)$, ve skupině vysokoškoláků zjišt’ujeme silný efekt „uznání rovnosti mužů a žen jako rodičư “ na vstup do manželství $(1,661=-0,453+2,114)$. Šance vysokoškolsky vzdělaných lidí, kteří uznávají rovnost mužů a žen jako rodičů, je oproti méně vzdělaným lidem, kteří uznávají tuto hodnotu, výrazně větší exp $(1,661)=5,3$ krát (viz Tabulka 9). Vypadá to tedy, že efekt „uznání rovnosti rodičư c působí pouze u vysokoškolsky vzdělaných, a to ve prospěch vyšší šance na vstup do manželství. Působí tedy přesně opačně, než jsme předpokládali na základě teoretických argumentů. 
Tabulka 9: Odhadnuté efekty (a jejich statistická signifikance) vybraných modelů binární logistické regrese na přirozený logaritmus šance, že respondent během sledovaného období uzavře první sňatek.

\begin{tabular}{|c|c|c|c|c|c|c|}
\hline & M8 & M11 & M16 & M21 & M28 & M29 \\
\hline \multirow[t]{2}{*}{ Materialismus } & 1,006 & & & & & \\
\hline & $(0,08)$ & & & & & \\
\hline \multirow[t]{2}{*}{ Religiozita } & & 0,180 & & & & \\
\hline & & $(0,61)$ & & & & \\
\hline \multirow[t]{2}{*}{ Seberealizace } & & & $-0,440$ & & & \\
\hline & & & $(0,19)$ & & & \\
\hline \multirow[t]{2}{*}{$\begin{array}{l}\text { Nerovnost zaměstnání a práce } \\
\text { v domácnosti }\end{array}$} & & & & $-0,086$ & & \\
\hline & & & & $(0,81)$ & & \\
\hline \multirow[t]{2}{*}{$\begin{array}{l}\text { Uznání rovnosti mužũ a žen } \\
\text { jako rodičú }\end{array}$} & & & & & $-0,453$ & $-1,414$ \\
\hline & & & & & $(0,56)$ & $(0,19)$ \\
\hline \multicolumn{7}{|c|}{ Vzdělání (vyučení a nižší - ref.kategorie) } \\
\hline \multirow[t]{2}{*}{ Maturitní } & 0,637 & 0,607 & 0,695 & 0,605 & 0,530 & 0,685 \\
\hline & $(0,08)$ & $(0,09)$ & $(0,05)$ & $(0,09)$ & $(0,17)$ & $(0,06)$ \\
\hline \multirow[t]{2}{*}{ Vysokoškolské } & 0,448 & 0,478 & 0,634 & 0,478 & $-0,204$ & 0,442 \\
\hline & $(0,35)$ & $(0,31)$ & $(0,19)$ & $(0,31)$ & $(0,74)$ & $(0,35)$ \\
\hline
\end{tabular}

Hlavní ekonomická aktivita (jiná ekonomická aktivita - ref.kategorie)

\begin{tabular}{|l|r|r|r|r|r|r|}
\hline Pracující & 0,818 & 0,297 & 0,302 & 0,313 & 0,318 & $-0,101$ \\
\hline & $(0,11)$ & $(0,44)$ & $(0,44)$ & $(0,42)$ & $(0,41)$ & $(0,81)$ \\
\hline
\end{tabular}

Věk v r. 2005 (18-24 - ref. kategorie)

\begin{tabular}{|c|r|r|r|r|r|r|}
\hline $25-29$ & 1,243 & 1,167 & 1,110 & 1,156 & 1,167 & 1,282 \\
\hline & $(0,01)$ & $(0,01)$ & $(0,02)$ & $(0,01)$ & $(0,01)$ & $(0,01)$ \\
\hline $30-34$ & 1,343 & 1,267 & 1,242 & 1,274 & 1,261 & 1,310 \\
\hline & $(0,01)$ & $(0,01)$ & $(0,01)$ & $(0,01)$ & $(0,01)$ & $(0,01)$ \\
\hline $35-39$ & 0,258 & 0,198 & 0,087 & 0,201 & 0,251 & 0,234 \\
\hline & $(0,76)$ & $(0,81)$ & $(0,92)$ & $(0,81)$ & $(0,76)$ & $(0,78)$ \\
\hline $40-44$ & 0,678 & 0,636 & 0,631 & 0,668 & 0,712 & 0,766 \\
\hline & $(0,36)$ & $(0,39)$ & $(0,39)$ & $(0,36)$ & $(0,34)$ & $(0,30)$ \\
\hline Pohlaví (žena-0, muž-1) & $-0,696$ & $-0,673$ & $-0,654$ & $-0,677$ & $-0,715$ & $-0,682$ \\
\hline & $(0,03)$ & $(0,04)$ & $(0,04)$ & $(0,03)$ & $(0,03)$ & $(0,04)$ \\
\hline
\end{tabular}

\section{Interakce}

Materialismus * pracující

Rovnost rodičů * maturitní vzdělání

\begin{tabular}{|r|r|l|l|l|r|r|}
\hline & $-1,229$ & & & & & \\
\hline & $(0,08)$ & & & & & \\
\hline & & & & & 0,451 & \\
\hline
\end{tabular}




\begin{tabular}{|l|r|r|r|r|r|r|}
\hline & \multicolumn{1}{|c|}{ M8 } & \multicolumn{1}{c|}{ M11 } & \multicolumn{1}{c|}{ M16 } & \multicolumn{1}{c|}{ M21 } & \multicolumn{1}{c|}{ M28 } & \multicolumn{1}{c|}{ M29 } \\
\hline Rovnost rodičů * vš vzdělání & & & & & 2,114 & \\
\hline & & & & & $(0,05)$ & \\
\hline Rovnost rodičũ * pracující & & & & & & 2,216 \\
\hline Konstanta & & & & & & $(0,05)$ \\
\hline & $-3,807$ & $-3,350$ & $-3,060$ & $-3,288$ & $-3,229$ & $-3,187$ \\
\hline
\end{tabular}

Zdroj: GGS 2005, 2008. N = 615.

Zatímco efekt „uznání rovnosti mužů a žen jako rodičů “ pro respondenty s ,jinou hlavní ekonomickou aktivitou“ je záporný $(-1,414)$, pro skupinu pracujících nabývá kladné hodnoty $0,802=-1,414+2,216$ (viz Tabulka 9). „Uznání rovnosti mužů a žen jako rodičưu ve skupině pracujících funguje opačně, než předpokládala naše hypotéza o genderové symetrii.

V oblasti výzkumu genderové rovnosti a rodinného chování se autoři věnují spíše než vstupu do manželství otázkám plodnosti. Ani v oblasti výzkumu plodnosti v různých zemích ale nebyla prokázána jasná a jednostranná tendence vlivu genderově rovných postojů. Dommermuth, Hohmann-Marriott a Lappegard (2013) a Neyer et al. (2013) rozlišili několik dimenzí genderové rovnosti, vliv každé $\mathrm{z}$ nich byl odlišný a odvíjel se od pořadí narozeného dítěte.

\section{Závěr a diskuse}

Cílem tohoto textu bylo ověřit, zda ne/vstupování do manželství v české společnosti probíhá podle vzorce předpovězeného teorií druhého demografického přechodu. Zjišt’ovali jsme proto, zda (a do jaké míry) hodnotový profil predikuje uzavření prvního sňatku. Dále jsme chtěli ukázat, zda je vliv hodnotového profilu zprostředkován vzděláním či hlavní ekonomickou aktivitou. V datech jsme našli jen dílčí oporu pro naše vstupní hypotézy. Vliv jednotlivých hodnotových proměnných (postmaterialismu, religiozity, preference genderové rovnosti v zaměstnání a v rodičovství) na pravděpodobnost vstupu do manželství se jevil ve většině př́padů jako nevýznamný, a to i při statistické kontrole vlivu dalších proměnných.

Ukázali jsme nicméně, že existovaly některé významné interakce mezi vybranými hodnotovými proměnnými a socioekonomickým postavením jedince. Vliv hodnot se konkrétně projevil u zvýšeného vlivu materialismu (ve srovnání s ne-materialismem) na vstup do manželství, což ale platilo pouze u osob mimo trh práce. Materialismus funguje tedy jen v části populace tak, jak to postuluje teorie druhé demografické tranzice.

Vliv hodnot jsme také našli u pracujících a u vysokoškolsky vzdělaných respondentů. Šlo nicméně o efekty, které působily opačným směrem, než předvídá sociologická teorie. Konkrétně u vysokoškoláků a pracujících platilo, že důraz na hodnoty rovnosti mužů a žen (at' už ve sféře kariérní nebo v oblasti péče o děti) zvyšoval šanci na vstup do manželství. Konečně religiozita nemá na pravděpodobnost vstupu do manželství vůbec žádný vliv.

Celkově se nám zdá, že identifikujeme mnohem slabší vliv hodnotových proměnných na vstup do manželství, než předpovídá teorie druhé demografické tranzice. To je překvapivé, nebot' se zdá být intuitivně validním výkladem soudobých populačních změn v ČR a v její 
prospěch hovořila dosavadní, byt' metodologicky třeba nedokonalá, empirická evidence (viz Gerber a Berman 2010; Kreidl 2010, 2012).

Při interpretaci výsledků analýzy je vhodné vzít do úvahy několik metodologických okolností. Měli jsme k dispozici data ze dvou vln panelového šetření. Uvažovali jsme kauzalitu směrem od hodnot k uzavření či neuzavření sňatku. Hypotézy o očekávaném vlivu proměnných jsme z části nepotvrdili. Můžeme spekulovat o tom, že kauzalita mezi uzavřením či neuzavřením sňatku a hodnotovým profilem je opačná, než jsme zde předjímali. To znamená, že manželství podporuje materialistické hodnoty a religiozitu a naopak oslabuje hodnoty genderové rovnosti a seberealizace v práci (srov. Smock 2000: 14-15; Thornton, Axinn a Hill 1992). Dalším faktorem, který hraje roli v tom, že jsme vliv hodnotových proměnných neodhalili, může být cenzorování dat zprava. Sledovali jsme svobodné ve věku 18-44 let v omezeném časovém horizontu tří let. Domníváme se proto, že efekt hodnotových proměnných pro vstup do manželství by se mohl projevit v př́padě, že bychom měli k dispozici kompletní informace o tom, kteří z respondentů vstoupí do manželství v průběhu života a kteří zůstanou svobodní. Odhady efektů hodnotových proměnných na vstup do manželství by mohly dále zpřesnit informace o hodnotách obou potenciálních manželů. My jsme vstup do manželství predikovali pomocí hodnot, které deklaroval respondent jako pouze jeden z potenciálních partnerů pro manželství. Je také možné, že se vliv hodnot projeví pouze tehdy, pokud se shodný hodnotový profil vyskytuje u obou partnerů. Tyto dvě doplňující teze nejsme schopni s dostupnými českými daty prověřit.

Konečně upozorňujeme na poměrně vysokou úmrtnost panelu (přes 65 \%), která může mít zásadní dopad na reprezentativitu analytického vzorku a může i vychýlit bodové odhady jednotlivých efektů. Přesto se domníváme, že je vhodné naše výsledky zveřejnit. Doposud nikdo pomocí panelových dat vliv hodnot na matrimoniální chování neanalyzoval, což reprezentuje významné bílé místo ve studiu populačních změn v současné české společnosti. Proto chceme data - byt' neúplná - v maximální možné míře analyticky vytěžit a nabídnout odborné komunitě ještě předtím, než někdo iniciuje sběr nových panelových dat s podobnou tematikou.

Zdá se nám, že vysokou úmrtnost dat z české části projektu Gender and Generations nelze pro účely našich (anebo podobných) analýz dostatečně spolehlivě opravit pomocí běžných nástrojů na doplnění chybějících dat, jako jsou např. mnohonásobné imputace, protože zde nejde o doplnění relativně malé části dat, ale o naprosto zásadní výpadek z původního vzorku. Proto výsledky - navzdory pochybnostem o reprezentativitě dat - prezentujeme pomocí nejjednodušší metody práce s chybějícími daty, metody listwise.

\section{Literatura}

BONGAARTS, John. Fertility and Reproductive Preferences in Post-Transitional Societies [online]. Paper prepared for the Conference on Global Fertility Transition, Bellagio, Italy, May 1998. [cit. 16. 9. 2013]. Dostupné z: http://www.popcouncil.info/pdfs/wp/114.pdf.

BUKODI, Erzsebet. The relationship between work history and partnership formation in cohorts of British men born in 1958 and 1970. Population Studies, 2012, roč. 66, č. 2, s. 123-145. ISSN $0032-4728$. 
CHEN, Xiao, Phil ENDER, Michael MITCHELL a Christine WELLS. Stata Web Books: Logistic Regression with Stata [online]. IDRE: Statistics Web Server, 2013 [cit. 4. 10. 2013]. Dostupné z: http:// www.ats.ucla.edu/stat/stata/webbooks/logistic/.

CLEVES, Mario, William W. GOULD, Roberto G. GUTIERREZ a Yulia MARCHENKO. An Introduction to Survival Analysis Using Stata. 3. vyd. College Station: Stata Press, 2010. ISBN 978-1597180740.

COLEMAN, David. New patterns and trends in European fertility: international and sub-national comparisons. In COLEMAN, David (ed.). Europe's population in the 1990s. New York: Oxford University Press, 1996, s. 1-61. ISBN 9780198288947.

ČERMÁKOVÁ, Marie. Rodina a měnící se gender role - sociální analýza české rodiny [online]. Praha: Sociologický ústav AV ČR, 1997 [cit. 2. 9. 2013]. Dostupné z: http://studie.soc.cas.cz/upl/texty/ files/153_97-8wptext.pdf.

ČERMÁKOVÁ, Marie a Hana MǍ̌íKOVÁ. Proměny současné české rodiny. Praha: Sociologické nakladatelství, 2000. ISBN 8085850931.

ČESKÝ SVAZ ŽEN. Překážky a možnosti ve slad'ováni práce a rodiny. Závěrečná studie fáze Analýza [online]. Projekt: Podmínky pro slad'ování práce a rodiny-partnerství v rodině, 2003 [cit. 2. 9. 2013]. Dostupné z: http://www.equalcr.cz/files/clanky/911/zaverecna_studie_analyza.pdf.

ČSÚ. Vývoj sňatečnosti a rozvodovosti v ČR po roce 1989. ČSÚ. Český statistický úřad [online]. (C2002 [cit. 29. 8. 2013]. Dostupné z: http://www.czso.cz/cz/cisla/1/11/111202/111202.htm.

ČSÚ. Vývoj úrovně vzdělanosti obyvatelstva v ČR v letech 1950 až 2001. ČSÚ. Český statistický úr̆ad [online]. C2003 [cit. 2. 9. 2013]. Dostupné z: http://www.scitani.cz/csu/2003edicniplan.nsf/t/ 57004FC6F8/\$File/411303a2.pdf.

ČSÚ. Náboženské vyznání obyvatelstva České republiky. Tisková zpráva. ČSÚ. Český statistický úřad [online]. (C2004 [cit. 2.9.2013]. Dostupné z: http://www.czso.cz/csu/tz.nsf/i/nabozenske_vyznani_ obyvatelstva_ceske_republiky_23_12_04.

ČSÚ. Obyvatelstvo podle dosaženého vzdělání. ČSÚ. Český statistický úřad [online]. C2011 [cit. 12. 8. 2013]. Dostupné z: http://www.czso.cz/sldb2011/redakce.nsf/i/obyvatelstvo_podle_dosazeneho_ vzdelani.

ČSÚ. Demografická př́ručka 2011. ČSÚ. Český statistický úřad [online]. C2012a [cit. 29. 8. 2013]. Dostupné z: http://www.czso.cz/csu/2012edicniplan.nsf/publ/4032-12-n_2012.

ČSÚ. Sňatečnost. ČSÚ. Českýstatistický úrad [online]. (C2012b [cit. 1. 4. 2014]. Dostupné z: http://www. czso.cz/csu/2012edicniplan.nsf/t/6A002ECDC5/\$File/400712a2.pdf.

DE SINGLY, Francois. Sociologie současné rodiny. Praha: Portál, 1999. ISBN 8071782491.

DOMMERMUTH, Lars, Bryndl HOHMANN-MARRIOTT a Trude LAPPEGARD. Gender equality in the family and childbearing. Discussion Papers, 2013, č. 759. Oslo: Statistics Norway. ISSN 0809-733X.

DUDOVÁ, Radka a Marta VOHLÍDALOVÁ. Souvislosti proměn pracovního trhu a forem soukromého, rodinného a partnerského života v české společnosti - teoretická studie. Praha: Sociologický ústav AV ČR, 2005. ISBN 9788073301194.

GERBER, Theodore a Danielle BERMAN. Entry to Marriage and Cohabitation in Russia, 1985-2000. Trends, Correlates, and Implications for the Second Demographic Transition. European Journal of Population, 2010, roč. 25, č. 1, s. 3-31. ISSN 0168-6577.

GUO, Guang. Event-History Analysis for Left-Truncated Data. Sociological Methodology, 1993, roč. 23, s. 217-243. ISBN 0081-1750.

HAŠKOVÁ, Hana a Ladislav RABUŠIC. K nízké sňatečnosti v České republice. Sociální studia, 2008, roč. 5, č. 2, s. 9-33. ISSN 1214-813X.

HOEM, Jan M., Dora KOSTOVA, Aiva JASILIONIENE a Cornelia MURESAN. Traces of the Second Demographic Transition in Four Selected Countries in Central and Eastern Europe: Union 
Formation as a Demographic Manifestation. European Journal of Population, 2009, roč. 25, č. 3, s. 239-255. ISSN 0168-6577.

INGLEHART, Ronald. The Silent Revolution in Europe: Intergenerational Change in Post-Industrial Societies. The American Political Science Review, 1971, roč. 65, č. 4, s. 991-1017. ISSN 0003-0554.

JONES, Gavin W., Yanxia ZHANG a Pamela C. P. ZHI. Understanding High Levels of Singlehood in Singapore. Journal of Comparative Studies, 2012, roč. 43, č. 5, s. 731-750. ISSN 0047-2328.

KALMIJN, Matthijs. The Influence of Men's Income and Employment on Marriage and Cohabitation: Testing Oppenheimer's Theory in Europe. European Journal of Population, 2011, roč. 27, č. 3, s. 269-293. ISSN 0168-6577.

KATRŇÁK, Tomáš. Strukturální př́íčiny poklesu sňatečnosti a nárůstu svobodných v devadesátých letech v České republice. Sociologický časopis, 2001, roč. 37, č. 2, s. 225-239. ISSN 0038-0288.

KREIDL, Martin. Dochází v ČR ke konvergenci hodnotového profilu lidí žijících v manželství a nesezdaném soužití? Sociálni studia, 2010, roč. 7, č. 4, s. 85-100. ISSN 1214-813X.

KREIDL, Martin. Educational Stratification of Marriage Entry under Different Political and Economic Regimes: Evidence from the Czech Republic during the Second Half of the 20th century. Population Review, 2012, roč. 41, č. 2, s. 151-178. ISSN 1549-0955.

KREIDL, Martin a Jaroslava HASMANOVÁ MARHÁNKOVÁ (eds.). Proměny partnerství. Životni dráhy a partnerství v české společnosti. Praha: Sociologické nakladatelství, 2012. ISBN 9788074191428.

KUCHAŘOVÁ, Věra. GGS - Wave 2. Czech Republic [online]. Research Institute for Labour and Social Affairs, 2009 [cit. 12. 8. 2013]. Dostupné z: http://www.unece.org/fileadmin/DAM/pau/_docs/ ggp/2009/IWG/GGP_2009_IWG007_Czech_Republic.pdf.

KVAPILOVÁ BARTOŠOVÁ, Michaela, Petr FUČ́́K a Petr PAKOSTA. Dlouhodobý vývoj v časování porodů a sňatků: Obstojí individualizační teorie ve světle demografických dat? Sociologický časopis, 2012, roč. 48, č. 2, s. 315-341. ISSN 0038-0288.

LAKOMÝ, Martin. Postmaterialismus v České republice: Revoluce tichá, nebo žádná? Brno, 2012. Bakalářská práce. Masarykova univerzita, Fakulta sociálních studií, Katedra sociologie.

LESTHAEGHE, Ron. The Second Demographic Transition In Western Countries: An Interpretation. IPD-Working Paper. Brussel: Vrije Universiteit, 1991-2.

LESTHAEGHE, Ron. The Unfolding Story of the Second Demographic Transition. Population and Development Review, 2010, roč. 36, č. 2, s. 211-251. ISSN 0098-7921.

LESTHAEGHE, Ron a Johan SURKYN. New Forms of Household Formation in Central and Eastern Europe: Are They Related to Newly Emerging Value Orientations? Interuniversity papers in demography. Brussel: Interface Demography (SOCO), Vrije Universiteit, 2002.

NEŠPOR, Zdeněk R. Přiliš slábi ve víre. Česká ne/religiozita v evropském kontextu. Praha: Kalich, 2010. ISBN 9788070171479.

NEYER, Gerda, Trude LAPPEGARD a Daniele VIGNOLI. Gender Equality and Fertility: Which Equality Matters? European Journal of Population, 2013, roč. 29, č. 3, s. 245-272. ISSN 0168-6577.

OPPENHEIMER, Valerie K. A Theory of Marriage Timing: Assortative Mating under Varying Degrees of Uncertainty. American Journal of Sociology, 1988, roč. 94, č. 3, s. 563-591. ISSN 0002-9602.

OPPENHEIMER, Valerie K. Women's Employment and the Gain to Marriage: The Specialization and Trading Model. Annual Review of Sociology, 1997, roč. 23, s. 431-453. ISSN 0360-0572.

OPPENHEIMER, Valerie K, Matthijs KALMIJN a Nelson LIM. Men's Career Development and Marriage Timing During a Period of Rising Inequality. Demography, 1997, roč. 34, č. 3, s. 311-330. ISSN 0360-0572.

PAPEŽSKÁ RADA PRO RODINU. Rodina, manželství a ,fakticky existující soužití “. Praha: Sekretariát České biskupské konference, 2001. 
PASTOR, Martinez J. I. Less and later: an analysis of male nuptiality during the last 30 years in Spain. Revista Espanola de Investigaciones Sociologicas, 2008, č. 123, s. 59-86. ISSN 0210-5233.

POTARCA, Gina, Melinda MILLS a Laurent LESNARD. Family Formation Trajectories in Romania, the Russian Federation and France: Towards the Second Demographic Transition? European Journal of Population, 2013, roč. 29, č. 1, s. 69-101. ISSN 0168-6577.

RABUŠIC, Ladislav. Je česká společnost postmaterialistická? Sociologický časopis, 2000, roč. 36, č. 1, s. 3-22. ISSN 0038-0288.

RABUŠIC, Ladislav. Value Change and Demographic Behaviour in the Czech Republic. Czech Sociological Review, 2001, roč. 9, č. 1, s. 99-122. ISSN 1210-3861.

RYCHTAŘÍKOVÁ, Jitka. Současné změny charakteru reprodukce v České republice a mezinárodní situace. Demografie, 1996, roč. 38, č. 2, s. 77-89. ISSN 0011-8265.

RYCHTAŘÍKOVÁ, Jitka. Nechci této společnosti namlouvat, že se nic neděje. Demografie, 1997, roč. 39, č. 4, s. 267-268. ISSN 0011-8265.

RYCHTAŘ́KOVÁ, Jitka. Is Eastern Europe experiencing a second demographic transition? Acta Universitas Carolinae Geographica, 1999, č. 1, s. 19-44. ISSN 0300-5402.

RYCHTAŘÍKOVÁ, Jitka. Demographic transition or demographic shock in recent population development in the Czech Republic? Acta Universitas Carolinae Geographica, 2000, č. 1, s. 89-102. ISSN 0300-5402.

ŘEHÁKOVÁ, Blanka. Změny hodnot v České republice a Inglehartova hodnotová typologie. Sociálni studia, 2001, č. 6, s. 47-71. ISSN 1212-365X.

SC\&C. GGS - Muži a ženy v ČR: životní dráhy. 1. část dotazníku - rozhovor. Generations and Gender Survey Czech Republic. Základni informace o projektu [online]. 2011a [cit. 1. 4. 2014]. Dostupné z: http://www.czech-ggs.cz/fi le/4/ggs_dotaznik.pdf.

SC\&C. Muži a ženy v ČR: životní dráhy a mezigenerační vztahy - 2. část. Generations and Gender Survey Czech Republic. Základní informace o projektu [online]. 2011b [cit. 1. 4. 2014]. Dostupné z: www.czech-ggs.cz/fi le/5/ggs_dotaznik_selfcompsmall.pdf.

SMOCK, Pamela J. Cohabitation in the United States: An Appraisal of Research Themes, Findings, and Implications. Annual Review of Sociology, 2000, roč. 26, s. 1-20. ISSN 0360-0572.

STLOUKAL, Libor. Changing patterns of extramarital conceptions in the Czech Republic, 1960-1993. Journal of biosociological sciences, 1997, roč. 29, č. 4, s. 471-489. ISSN 0021-9320.

STLOUKAL, Libor. Declining nuptiality in the Czech Republic, 1989-1996: The second demographic transition in progress? Annual Conference of the British Society for Population Studies. 1998, Cambridge: British Society for Population Studies.

SOBOTKA, Tomáš, Kryštof ZEMAN a Vladimíra KANTOROVÁ. Second demographic transition in the Czech Republic: Stages, specific features and underlying factors. Konference „The second demographic transition in Europe “. Červen 2001, Bad Herrenalb: EURESCO.

SOBOTKA, Tomáš, Kryštof ZEMAN a Vladimíra KANTOROVÁ. Demographic shifts in the Czech Republic after 1989: A second demographic transition view. European Journal of Population, 2003, roč. 19, č. 3, s. 249-277. ISSN 0168-6577.

THORNTON, Arland, William G. AXINN a Daniel H. HILL. Reciprocal Effects of Religiosity, Cohabitation, and Marriage. American Journal of Sociology, 1992, roč. 98, č. 3, s. 628-651. ISSN 0002-9602.

THORNTON, Arland, William G. AXINN a Yu XIE. Marriage and Cohabitation. Chicago: University of Chicago Press, 2007. ISBN 9780226798660.

TUČEK, Milan a Alena KŘÍŽKOVÁ. Zaměstnání versus rodina - dělba rolí v rodině. In TUČEK, Milan (ed.). Česká rodina v transformaci - Stratifikace, dělba rolí a hodnotové orientace. Praha: Sociologický ústav AV ČR, 1998, s. 80-87. ISBN: 8085950456. 
VAN DE KAA, Dirk J. Europe's Second Demographic Transition. Population Bulletin, 1987, roč. 42, č. 1, s. 1-59. ISSN 0032-468X.

VAN DE KAA, Dirk J. Demographic transitions. NIDI Working Paper, č. 1 [online]. Hague: NIDI 2008 [cit. 15.5.2013]. Dostupnéz: http://www.nidi.nl/shared/content/output/papers/nidi-wp-2008-01.pdf.

VÁNĚ, Jan a Martina ŠTÍPKOVÁ. The National Religious Environment and the Orthodoxy of Christian Beliefs: A Comparison of Austria, the Czech Republic and Slovakia. Sociologický časopis, 2013, roč. 49, č. 3, s. 403-425. ISSN 0038-0288.

XIE, Yu, James M. RAYMO, Kimberl GOYETTE a Arland THORNTON. Economic Potential and Entry into Marriage and Cohabitation. Demography, 2003, roč. 40, č. 2, s. 351-367. ISSN 0070-3370.

\section{Autor a autorka}

Martin Kreidl vystudoval postgraduálně sociologii na Kalifornské univerzitě v Los Angeles a na Fakultě sociálních věd Univerzity Karlovy v Praze. V současnosti působí jako docent na Katedře sociologie a Ústavu populačních studií Fakulty sociálních studií Masarykovy univerzity $\mathrm{v}$ Brně. Zabývá se výzkumem sociálních nerovností, rodiny a populačními studiemi.

Lucie Moravcová vystudovala bakalářský obor sociologie na Fakultě sociálních studií Masarykovy univerzity $\mathrm{v}$ Brně. V současnosti tamtéž pokračuje $\mathrm{v}$ magisterském studiu sociologie. 